\title{
Inheritance of Phosphoglucoisomerase in Fountain Grass
}

\author{
M. Hockenberry Meyer'and Donald B. White ${ }^{2}$ \\ Department of Horticultural Science, University of Minnesota, St. Paul, MN 55108 \\ Additional index words. Pennisetum alopecuroides, kozymes
}

\begin{abstract}
Starch gel electrophoresis was used to screen 10 enzyme systems for variation in fountain grass, Pennisetum alopecuroides (L.) Spreng. plants exhibiting four different growth habits: dwarf(d), mound(m), prostrate(p), and upright (u). Only phosphoglucoisomerase (PGI; E.C. 5.3.1.9) was found to be polymorphic at one locus, PGI-2, and was expressed as two alleles, which appeared to be associated with growth habit. The dwarf form expressed one slow band (SS), the mound and prostrate forms exhibited one fast band (FF), and the upright form carried triple bands indicating a heterodimer (FS). Hybrids between FF and SS parents were detected as triple bands (FS). Three generations of progeny resulting from 16 crosses and selfs of these growth habits all followed the expected segregation ratios for typical Mendelian inheritance of this isozyme.
\end{abstract}

Fountain grass is an attractive ornamental, $2 \mathrm{n}=18$ (Ono and Tateoka, 1953), typically 90-125 cm tall with many purple or mauve inflorescences that give the plants the appearance of a fountain in August and September in the northern temperate zone (Bailey, 1949; Meyer, 1975). Although its popularity has increased in the past 10 years, no records of any genetic improvement have been reported. Fountain grass is native over a large area from northern Manchuria (Kitagawa, 1979) southward to New South Wales in Australia (Wheeler et al., 1982), so it is likely that many forms and variants exist. In 1987, a breeding program for fountain grass was initiated at the Univ. of Minnesota with the goal of selecting new ornamental forms. Initial accessions revealed four growth habits, which were identified as dwarf, mound, prostrate and upright.

Isozymes offer several applications in studying germplasm collections, such as separation and classification of genotypes (Tanksley and Orton, 1983), plant identification (Cousineau and Donnelly, 1992), tagging of economic traits (Rick and Fobes, 1974), and studying phylogenetic relationships within a species (Tostain and Marchais, 1989). The purpose of this research was to use isozyme analysis to classify the variation in fountain grass germplasm and to determine isozyme inheritance.

\section{Materials and Methods}

Plants or seeds of fountain grass were acquired from several sources. Material received as plants was field grown in a Waukegan silt loam soil in St. Paul, Minn., or in a Hayden loam soil at the Univ. of Minnesota Landscape Arboretum in Chanhassen. Seeds were germinated in the greenhouse and seedlings transplanted to the field.

All plants were evaluated for variation by measuring 13 morphological characters. After 2 years, 4 growth habits-dwarf, mound, prostrate, and upright-were identified. Detailed descriptions of these growth habits and their inheritance have been reported (Meyer, 1993). The dwarf growth habit was obtained as bareroot plants from John Greenlee Nursery, Pomona, Calif., and

Received for publication 31 May 1994. Accepted for publication 19 Dec. 1994. Paper no. 20,822 of the Scientific Journal Series, Univ. of Minnesota Agricultural Experiment Station. The cost of publishing this paper was defrayed in part by the payment of page charges, Under postal regulations, this paper therefore must be hereby marked advertisement solely to indicate this fact.

'Assistant professor.

${ }^{2}$ Professor. was labeled Pennisetum alopecuroides 'Weserbergland'. The mound and prostrate plants were received as seed (PI 90190, origin Korea) from the U.S. Dept. of Agriculture Plant Introduction Station Germplasm Laboratory in Experiment, Ga. The upright growth habit was received as bareroot plants from K. Bluemel Nursery, Baldwin, Md.

Four plants, one of each growth habit, were selected for use as parents and crossed in a complete diallel during August 1990 and repeated in August 1991.

Fountain grass, like other species of Pennisetum, is protogynous; the stigmas precede anther exertion and dehiscence by 2 to 5 days (Burton, 1974; Jauhar, 1981). Hybrids in pearl millet, Pennisetum glaucum (L.) R. Br., are made by taking advantage of this difference in anther and stigma emergence (Burton, 1991; Poehlman, 1986). Phenotypic variation and heterosis in progeny from fountain grass crosses evaluated in 1989 and 1990 confirmed controlled pollination had occurred without emasculation. Therefore, emasculation was not necessary to obtain the crosses reported in this paper. Inflorescences were bagged before stigma emergence. For the $\mathrm{F}_{1}$ crosses, the appropriate pollen was applied when stigmas were observed to be receptive and after pollination the heads were immediately rebagged. For selfs, inflorescences were bagged before stigma emergence and not removed until the seed was harvested. About 1 month after pollination, the inflorescences were collected, and each was cleaned and weighed separately.

From the original diallel, the $12 \mathrm{~F}_{1}$ and $4 \mathrm{~S}_{1}$ lines of seed were germinated on moistened blotter paper and then transplanted to cell packs in the greenhouse. In late May 1991 and 1992, seedlings were field-planted in a Waukegan silt loam soil type with 1 x $1-\mathrm{m}$ spacing in a randomized design by lines. The plants were maintained with normal cultural practices such as weeding, irrigation, and fertilization.

To obtain the second generation, all twelve $F_{1}$ and the four $S_{1}$ lines were selfed by bagging a minimum of five random heads per line before stigma emergence. At maturity, each inflorescence was collected and the seeds were cleaned and weighed. The following spring these seeds were germinated and the subsequent plants grown as outlined above.

The third generation was obtained by selfing all $\mathrm{S}_{1}$ and $\mathrm{S}_{2}$ lines by bagging a minimum of five random inflorescences prior to stigma emergence. Seeds were collected and cleaned as described above.

A total of $16 \mathrm{~F}_{1}$ and $\mathrm{S}_{1}$ progeny lines from $1990,16 \mathrm{~S}_{1}$ and $\mathrm{S}_{2}$ selfed lines from 1991, and $13 \mathrm{~S}_{2}$ and $\mathrm{S}_{3}$ selfed lines (three lines 


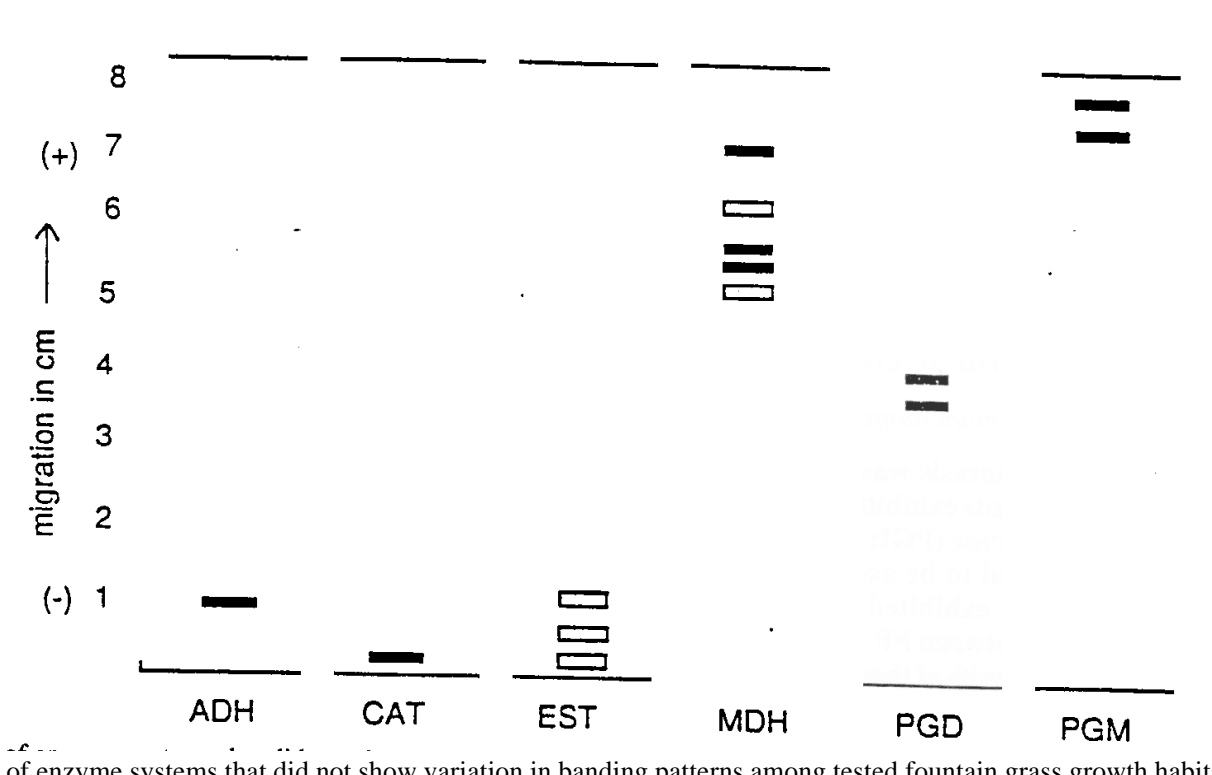

Fig. 1. Interpretive drawing of enzyme systems that did not show variation in banding patterns among tested fountain grass growth habits.

failed to set seed) from 1992 were screened for isozyme variation and inheritance.

For electrophoresis, individual dry seeds were crushed with a glass rod in ceramic wells containing $\approx 0.1 \mathrm{ml}$ of refrigerated extraction buffer as described by Leblanc and Pernes (1983). Young leaf tissue was used to screen the dwarf $\mathrm{S}_{2}$ plants, otherwise seeds were used for isozyme analysis. The electrophoretic buffer, stain, and gel recipes were as described by Morden et al. (1 987) and Cardy et al. (1983), but modified by using potato starch in place of corn starch. The extracts were absorbed onto paper wicks $(2 \times 11$ $\mathrm{mm}$, Whatman $3 \mathrm{MM}$ chromatography paper) that were loaded into the starch gels. Electrophoresis was conducted at $4 \mathrm{C}$ at $17 \mathrm{~W}, \approx 300$ volts. After $\approx 4 \mathrm{~h}$, the gels were sliced and stained.

Designation of isozymes was based on the migration distance from the origin of the extracts. The fastest migration (most anodal) enzyme was designated with the code F. Seed from the prostrate plant $\left(\mathrm{S}_{1}\right)$ was used as the control in most gels. Inheritance analyses were conducted using a $x^{2}$ goodness-of-fit test assuming monogenic and codominant expression of alleles at a single locus.

\section{Results and Discussion}

Alcohol dehydrogenase (ADH; E.C.1.1.1.1), catalase (CAT; E.C.1.11. 1.6), esterase (EST; E.C.3.1.1), malate dehydrogenase (MDH; E.C.1.1.1.40), phosphogluconate dehydrogenase (PGD; E.C.1.1.1.44), and phosphoglucomutase (PGM; E.C.5.4.2.2) were monomorphic for all plants tested (Fig. 1). Acid phosphotase (ACP; E. C.3.1.3.2), glutamate oxaloacetate transaminase (GOT; E.C.2.6.1.1), and isocitrate dehydrogenase (IDH; E.C.1.1.1.42) were difficult to resolve and require further investigation.

PGI exhibited two zones of activity, the one closest to the anode labeled PGI-1, was monomorphic and often very light (Fig. 2); the second, furthest from the anode, labeled PGI-2, was polymorphic and represented two alleles (Fig. 2). The banding pattern of PGI2 consisted of either one slow, one fast, or three bands, which suggests a dimeric enzyme structure (Fig. 3). In the original parents, seed from the dwarf plants expressed one slow band, SS; mound and prostrate $S_{1}$ seed exhibited one fast band, FF; and extracts from seeds of the upright plant formed a triple band, FS,

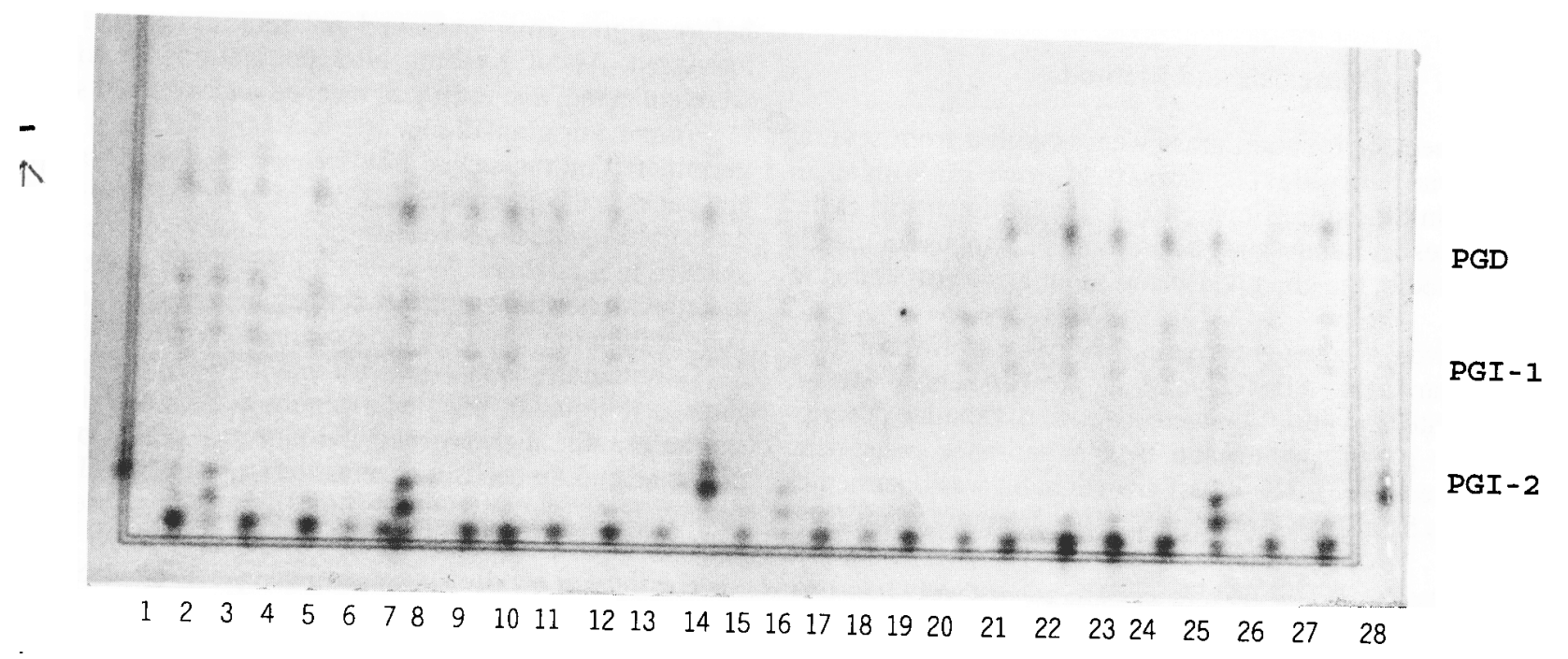

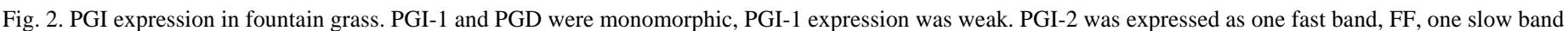
SS, or as a triple band, FS. Lanes 1, 14, and 28 are controls, dry seed from the prostrate plant, expressing FF alleles; the other 25 lanes are extracts from young leaf tissue of putative selfs from a dwarf parent. Plants with the FS alleles in lanes 3, 8, 16, and 25 were not phenotypic dwarfs, all other 21 lanes show the expected SS alleles and were dwarfs. 


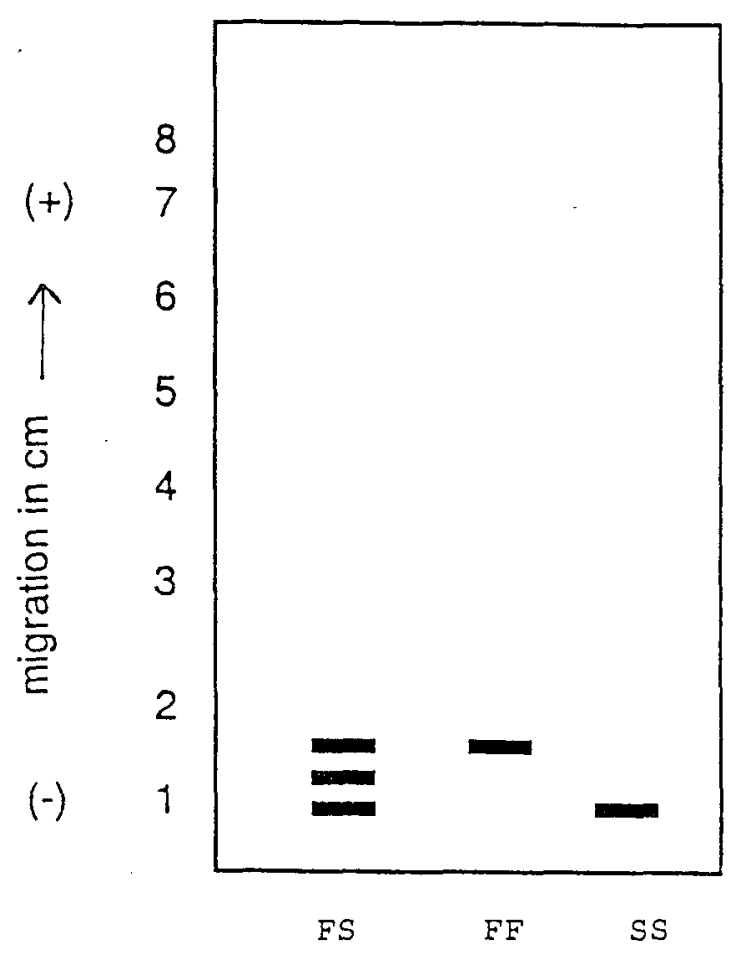

Fig. 3. Banding pattern of PGI-2 in fountain grass. SS, one slow band, was first expressed in the plants with a dwarf growth habit; FF indicating one fast band, was exhibited by the prostrate and mound plants and FS, a heterodimer, with three bands, was expressed by the upright growth habit plants.

or a heterodimer, indicating the heterozygote, FS.

All 46 lines tested ( 3 lines could not be tested due to failure to set seed) - the $F_{1}$ crosses, $S_{1}, S_{2}$, and $S_{3}$ progeny-showed the expected segregation patterns for simple monogenic inheritance at the PGI-2 locus (Table 1). Intraspecific hybrids could be identified in some crosses. Heterozygous plants were selected, when possible, for screening in the second and third generations. All selfed and hybrid progeny from prostrate and mound parents formed one fast band (data not shown). In the upright growth habit (FS), seed from six plants over the two generations were screened. Only one carried the FF alleles, the other five were heterozygotes (FS), and their seed segregated in a 1:2:1 ratio (Table 1$)$. High, yet acceptable $(P=0.16)$ levels of FS individuals were counted for the $S_{2}$ indicating the heterozygote maybe favored. The upright $x$ dwarf (FS x SS) and dwarf $x$ upnght progeny segregated 1FS: 1SS and the $S_{1}$ and $S_{2}$ plants selected were heterozygotes with progeny that segregated 1 FF: 2 FS $: 1 \mathrm{SS}$. Prostrate $\mathrm{x}$ upright (FF $\mathrm{x}$ FS) and the reciprocal cross resulted in a $1 \mathrm{FF}$ : $1 \mathrm{FS}$ segregation in the $\mathrm{F}_{1}$. Seed of the $S_{1}$ either segregated $1 \mathrm{FF}: 2 \mathrm{FS}$ : $1 \mathrm{SS}$ from a parent with FS alleles, or all progeny carried only FF alleles from a homozygous parent. In the upright $\mathrm{x}$ prostrate $\mathrm{S}_{2}, 25$ seed screened expressed only the F alleles, indicating a homozygous parent. Only two seed resulted in the prostrate $x$ upright $S_{3}$, not enough to verify segregation.

The prostrate $\mathrm{x}$ dwarf (FF $\mathrm{x}$ SS) cross and the reciprocal cross resulted in all FS individuals in the $F_{1} . S_{1}$ and $S_{2}$ progeny followed 1:2:1 segregation indicating heterozygous parents. Progeny from the upright $\mathbf{x}$ mound (FS $x$ FF) and the reciprocal cross segregated $1 \mathrm{FF}: 1 \mathrm{FS}$ as expected. All progeny screened in the $S_{1}$ and $S_{2}$ generations carried only the FF alleles, indicating homozygous parents. Eleven selfs could be detected along with 19 progeny in the mound $\mathrm{x}$ dwarf, FF x SS cross. Visual heterosis of these hybrid progeny was reported (Meyer, 1993) and was sufficient to ensure that only hybrids were selfed to obtain subsequent generations. All individuals tested in the reciprocal cross, dwarf $\mathrm{x}$ mound were hybrids (FS). Segregation from a heterozygous parent was as expected, a 1:2:1 in the $S$, and plants screened in the $S_{2}$ carried only FF alleles.

All $S_{1}$ progeny from the dwarf expressed only SS alleles. In the $\mathrm{S}_{2}, 69$ individuals were screened, all were expected to carry only SS alleles, but 5 were detected as FS. These five plants were identified as nondwarfs, or outcrosses (phenotypically distinct with coarse foliage and taller culms), in the $S_{2}$ population. In the zymogram for 25 of these putative selfed dwarfs, the four nondwarfs could be identified as heterodimers (Fig. 2). The remaining $\mathrm{S}_{2}$ 's were 30 dwarf plants that carried the two SS alleles. Although many in florescenses were bagged, only six seed were obtained for the $S_{3}$ generation, too few to verify segregation.

PGI appears to be a dimeric enzyme in fountain grass. PGI-2, as analyzed here, corresponds to the cytosolic locus of this enzyme which has been confirmed in several plants including spinach (Spinacia deracea) (Schnarrenberger and Oeser, 1974), tomato (Lycopersicon esculentum) (Tanksley and Rick, 1980), pearl millet Pennisetum glaucum) (Leblanc and Pernes, 1983), corn (Zea mays) (Goodman and Stuber, 1983), tepary bean (Phaseolus acutifolius var. latifolius) (Garvin et. al., 1989), and guayule (Parthenium argentatum) (Hashemi et al., 1991 ). These examples reinforce Gottlieb's (1982) review that subunit structure, number of loci, and subcellular localization of isozymes, especially those catalyzing steps in primary metabolism such as PGI in glycolysis, are well conserved in plant species.

In six lines of progeny [dwarf $\mathrm{x}$ mound; dwarf $\mathrm{x}$ prostrate; dwarf $\mathrm{x}$ upright; mound $\mathrm{x}$ dwarf, $\left(\mathrm{S}_{2}\right)$ prostrate $\mathrm{x}$ dwarf, and upright selfed], there were high levels of heterozygotes (FS) although the ratios fit $x^{2}$ expectations. Weeden and Wendel (1989) discuss skewed segregation ratios where isozyme loci were closely linked to genes or chromosomal segments exposed to strong selection pressures during gametophytic and postzygotic development. Mitton (1989) reported that at least some enzyme polymorphisms have a substantial impact on plant physiology and other reports suggest that heterozygous individuals can capture the highest fitness (Rainey et al., 1987) and maybe favored to compete and survive over homozygotes. The $\mathrm{S}$ allele maybe somehow linked or associated with a developmental disadvantage in the dwarf growth habit since low numbers of these individuals were detected. Dwarfism in pearl millet was reported as the result of the inability to use gibberellic acid (GA $)$ (Krishna Rao et al., 1981).

Whether or not the fountain grass individuals with a FS genotype are superior in gametophytic development or have a higher level of fitness in direct response to the enzyme produced by this PGI heterodimer remains unknown.

In conclusion, fountain grass expressed polymorphism at only one locus studied, PGI-2. The inheritance for three generations at this locus followed typical Mendelian segregation.

\section{Literature Cited}

Bailey, L.H. 1949. Manual of cultivated plants. Macmillan, New York. Burton, G.W. 1974. Factors affecting pollen movement and natural crossing in pearl millet. Crop. Sci. 14:802-805.

Burton, G. W. 1991. ASA abstracts. Five recurrent restricted phenotypic selection uses. ASA, Madison, Wis.

Cardy, B. J., C.W. Stuber, J.F. Wendel, and M.M. Goodman. 1983. Techniques for starch gel electrophoresis of enzymes in maize (Zea mays L.). North Carolina State Univ., Raleigh.

Cousineau, J.C. and D.J. Donnelly. 1992. Genetic analysis of isoenzymes in raspberry. J. Amer. Soc. Hort. Sci. 117:996-999.

Garvin, F., M.L. Roose, and J.G. Waines. 1989. Isozyme genetics and linkage in 


\begin{tabular}{|c|c|c|c|c|c|c|}
\hline \multirow[b]{2}{*}{ Cross } & \multicolumn{3}{|c|}{$\begin{array}{l}\text { uoservea } \\
\text { progeny } \\
\text { segregation }\end{array}$} & \multirow{2}{*}{$\begin{array}{c}\text { Expected } \\
\text { test } \\
\text { ratio }\end{array}$} & \multirow[b]{2}{*}{$\chi^{2}$} & \multirow[b]{2}{*}{$P$} \\
\hline & $\mathrm{FF}$ & $\mathrm{FS}$ & SS & & & \\
\hline \multicolumn{7}{|c|}{ Upright, selfed, FS } \\
\hline $\mathrm{S}_{1}$ & 14 & 17 & 10 & $1: 2: 1$ & 1.96 & 0.38 \\
\hline $\mathrm{S}_{2}(\mathrm{FS})^{\mathrm{z}}$ & 13 & 39 & 11 & $1: 2: 1$ & 3.69 & 0.16 \\
\hline $\mathrm{S}_{3}(\mathrm{FS})$ & 9 & 13 & 6 & $1: 2: 1$ & 0.78 & 0.68 \\
\hline \multicolumn{7}{|c|}{ Upright $x$ dwarf, FS $x$ SS } \\
\hline $\mathrm{F}_{1}$ & --- & 13 & 16 & $1: 1$ & 1.33 & 0.57 \\
\hline$S_{1}(F S)$ & 6 & 19 & 8 & $1: 2: 1$ & 0.99 & 0.61 \\
\hline $\mathrm{S}_{2}(\mathrm{FS})$ & 9 & 17 & 7 & $1: 2: 1$ & 0.27 & 0.87 \\
\hline \multicolumn{7}{|c|}{ Dwarf $x$ upright, SS $x$ FS } \\
\hline $\mathrm{F}_{1}$ & --- & 28 & 22 & $1: 1$ & 0.72 & 0.40 \\
\hline$S_{1}(F S)$ & 9 & 25 & 6 & $1: 2: 1$ & 2.95 & 0.23 \\
\hline $\mathrm{S}_{2}(\mathrm{FS})$ & 3 & 7 & 3 & $1: 2: 1$ & 0.07 & 0.96 \\
\hline \multicolumn{7}{|c|}{ Prostrate $x$ upright, FF x FS } \\
\hline $\mathrm{F}_{1}$ & 14 & 13 & --- & $1: 1$ & 0.04 & 0.85 \\
\hline$S_{1}(F F)$ & 24 & --- & --- & ..- & --- & --- \\
\hline $\mathrm{S}_{2}$ & 2 seed & --- & --- & --- & --- & --- \\
\hline \multicolumn{7}{|c|}{ Upright $\times$ prostrate, $F S \times F F$} \\
\hline $\mathrm{F}_{1}$ & 22 & 20 & --- & $1: 1$ & 0.09 & 0.75 \\
\hline$S_{1}(F S)$ & 7 & 24 & 8 & $1: 2: 1$ & 2.11 & 0.35 \\
\hline $\mathrm{S}_{2}(\mathrm{FS})$ & 5 & -.- & --- & --- & --- & --- \\
\hline \multicolumn{7}{|c|}{ Prostrate $x$ dwarf, FF x SS } \\
\hline $\mathrm{F}_{1}$ & --- & 31 & --. & --. & --- & --- \\
\hline $\mathrm{S}_{1}(\mathrm{FS})$ & 11 & 26 & 10 & $1: 2: 1$ & 0.51 & 0.77 \\
\hline $\mathrm{S}_{2}(\mathrm{FS})$ & 11 & 34 & 18 & $1: 2: 1$ & 1.95 & 0.38 \\
\hline \multicolumn{7}{|c|}{ Dwarf $x$ prostrate, $S S \times F F$} \\
\hline$F_{1}$ & --- & 29 & -.- & --- & --- & --- \\
\hline $\mathrm{S}_{1}(\mathrm{FS})$ & 13 & 23 & 5 & $1: 2: 1$ & 3.64 & 0.16 \\
\hline $\mathrm{S}_{2}(\mathrm{FS})$ & 13 & 28 & 9 & $1: 2: 1$ & 1.36 & 0.51 \\
\hline \multicolumn{7}{|c|}{ Upright $x$ mound, FS $\times$ FF } \\
\hline$F_{1}$ & 15 & 15 & -.- & $1: 1$ & 0.00 & 0.99 \\
\hline $\mathrm{S}_{1}(\mathrm{FF})$ & 26 & $\cdots$ & --- & $\cdots$ & --- & --- \\
\hline $\mathrm{S}_{2}(\mathrm{FF})$ & 30 & --- & --- & --- & --- & --- \\
\hline \multicolumn{7}{|c|}{ Mound $x$ upright, FF x FS } \\
\hline $\mathrm{F}_{1}$ & 24 & 26 & --- & $1: 1$ & 0.08 & 0.77 \\
\hline$S_{1}(\mathrm{FF})$ & 37 & --- & --- & --- & --- & --- \\
\hline $\mathrm{S}_{2}(\mathrm{FF})$ & 25 & --- & --- & --- & --- & -.- \\
\hline \multicolumn{7}{|c|}{ Mound x dwarf, FF x SS } \\
\hline $\mathrm{F}_{1}$ & 11 & 19 & --- & --- & --- & --- \\
\hline$S_{1}(F S)$ & 13 & 27 & 6 & $1: 2: 1$ & 3.49 & 0.18 \\
\hline $\mathrm{S}_{2}(\mathrm{FF})$ & 25 & --- & --- & --- & --- & --- \\
\hline \multicolumn{7}{|c|}{ Dwarf $x$ mound, $S S x$ FF } \\
\hline $\mathrm{F}_{1}$ & --- & 27 & --- & --- & --- & --- \\
\hline $\mathrm{S}_{1}(\mathrm{FS})$ & 15 & 28 & 7 & $1: 2: 1$ & 3.28 & 0.19 \\
\hline $\mathrm{S}_{2}(\mathrm{FF})$ & 10 & --- & & --- & --- & --- \\
\hline \multicolumn{7}{|l|}{ Dwarf, selfed, SS } \\
\hline $\mathrm{S}_{1}$ & --- & --- & 29 & --- & --- & -- \\
\hline $\mathrm{S}_{2}$ & --- & --- & 34 & --- & --- & --- \\
\hline $\mathrm{S}_{2}$ leaf samples & --- & 5 & 30 & --- & --- & $\cdots$ \\
\hline $\mathrm{S}_{3}$ & 6 seed & & & & & \\
\hline
\end{tabular}

2Parental genotype for PGI-2.

tepary bean Phaseolus acutifolius A. Grey. J. Hered. 80:373-376.

Goodman, M.M. and C.W. Stuber. 1983. Isozymes in maize, p. 219-239. In: S.O. Tanksley and T.J. Ortan (eds.). Isozymes in plant genetics and plant breeding. Part A. Elsevier, Amsterdam.

Gottlieb, L.D. 1982. Conservation and duplication of isozymes in plants.
Science 216:373-380.

Hashemi, A., A. Estilai, and B. Ehdaie. 1991. Inheritance of aconitase, shikimate dehydrogenase, and phosphoglucoseisomerase in guayle. J. Amer. Soc. Hort. Sci. 116:737-739.

Jauhar, P. 1981. Cytogenetics and breeding of pearl millet and related 
species. A.R. Liss, New York.

Krishna Rae, M.U. Koduru, and R.V. Krishna Rae. 1981. Dwarfism in pearl millet: its relation to gibberellic acid and coleoptile length. Beitr. Biol. Pflanz. 55:195-202.

Kitagawa, M. 1979. Neo-Lineamenta Florae Manshuricae. J. Cramer, Harbin, Manchuria.

Leblanc, J.M. and J. Pernes. 1983. Enzyme polymorphism of Pennisetum americanum in the Ivory Coast. Jpn. J. Genet. 58: 121-131.

Meyer, M. Hockenberry. 1975. Ornamental grasses. Charles Scribner's Sons, New York.

Meyer, M. Hockenberry. 1993. Inheritance of growth habit and phosphoglucoisomerase in Pennisetum alopecuroides (L.) Spreng. PhD diss. Univ. of Minnesota.

Mitton, J.B. 1989. Physiological and demographic variation associated with allozyme variation. In: D.E. Soltis and P. S. Soltis (eds.). Isozymes in plant biology. Discorides Press, Portland, Ore.

Morden, C. W., J. Doebley, and K.F. Schertz. 1987. A manual of techniques for starch gel electrophoresis of sorghum isozymes. Texas A \& M Univ. Press, College Station.

One, H. and T. Tateoka. 1953. Karyotaxonomy in Poaceae. I. Chromosomes and taxonomic relations in some Japanese grasses. Bet. Msg. Tokyo 66:775-776.
Poehlman, J.M. 1986. Breeding field crops. VanNostrand Reinhold, New York.

Rainy, D. Y., J.B. Mitton, and R.K. Monson. 1987. Associations between enzyme genotypes and dark respiration in perennial ryegrasss, Lolium perenne L. Oecologia 74:335-338.

Rick, C.M. and J.F. Fobes. 1974. Association of an allozyme with nematode resistance. Rpt. Tomato Genet. Coop. 24:25.

Schnarrenberger, C. and A. Oeser. 1974. Two isozymes of glucosephosphate isomerase from spinach leaves and their intracellular compartmentation. Eur. J. Biochem. 45:77-82.

Tanksley, S.D. and T.J. Orton. 1983. Isozymes in plant genetics and breeding. Part B. Elsevier, Amsterdam.

Tanksley, S.D. and C.M. Rick. 1980. Isozyme and gene linkage map of the tomato: applications in genetics and breeding. Theoretical Applied Genet. 57:161-170.

Tostain, S. and L. Marchais. 1989. Enzyme diversity in pearl millet (Pennisetum glaucum). Theoretical Applied Genet. 77:634-640.

Weeden, N. F. and J.F. Wendel. 1989. Genetics of plant isozymes. In: D.E. Soltis and P.S. Soltis (eds.). Isozymes in plant biology. Discondes Press. Portland, Ore.

Wheeler, D. J. B., S.W.L. Jacobs, and B.E. Norton. 1982. Grasses of New South Wales. Univ. of New England, Armidale, Australia. 